\title{
Dialogic positioning in Iranian versus Western media coverage of the Iranian nuclear issue
}

\author{
Ghane, Mohammad Hossein $₫$ \\ Yazd University, Iran (Ghane57@yahoo.com) \\ Allami, Hamid \\ Yazd University, Iran (Hamid_allami@yahoo.com) \\ Mahdavirad, Fatemeh \\ Yazd University, Iran (Fmahdavirad@yahoo.com)
}

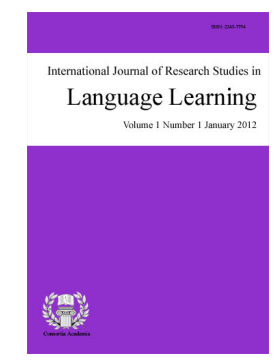

ISSN: $2243-7754$ Online ISSN: 2243-7762

OPEN ACCESS

\section{Abstract}

Working within the appraisal framework (Martin \& White, 2005), an attempt has been made to identify the dialogic positioning, by which texts can favor particular value positions while pretending to be sharing their readers' views through employment of certain lexical choices, hence stance markers. A set of Iranian and Western journalistic texts have been compared and contrasted to explore the ways Iranian and Western journalists employ such devices in the texts they develop for reporting the negotiations between Iran and 5+1 countries concerning the nuclear energy issues. Holding opposite positions regarding the Iranian nuclear issue, and employing different linguistic devices, both sides seem to have the same tendencies in this regard and made use of the contractively dialogic positioning more than the expansive one. The findings of the research indicate that media are a means in the hands of the powers in order to steer the public mind towards their favorite directions. In other words, events are not represented in the media as they are in reality, but go through journalistic practices.

Keywords: appraisal framework; media; dialogic positioning; stance markers; Iranian nuclear issue 


\section{Dialogic positioning in Iranian versus Western media coverage of the Iranian nuclear issue}

\section{Introduction}

As a strong means for governments for the realization of their intentions, media can play substantial influence on the lives of people today. They can do so simply through the utilization of language by aligning the minds of their audience with that of those in power. Many political issues have occurred in the last decades which have seriously influenced the lives of people in different corners of the world. Iran's nuclear program has been among the most outstanding issues in recent years which have been covered by media. The media have had the unquestionable role for the fulfillment of the policy makers' intentions and the Iranian nuclear issue has been no exception. The manner in which the media cover Iran's nuclear program is important to consider due to its influence on the nuclear negotiations and how the dispute can be resolved peacefully. The Western media have spread a strong effect on the Iranian nuclear energy program warning that Iran is carrying out secret nuclear activities which can cause a threat to the international peace and tranquility. Iranian media, on the other hand, have attempted to defend Iran's right to have atomic energy capability, reasoning that it is the future source of energy replacing fossil fuels. In this regard, the stance markers which the media on both sides have employed carry over the influence they have intended to convey to the readers.

A number of studies have already been conducted on stance markers in the field of critical discourse analysis (e.g. Behnam \& Mahoudi, 2013; Izadi \& Shaghaye Biria, 2007; Siegel \& Barforoush, 2013; Shojaei, Youssefi \& Shams Hosseini, 2013) on the Iranian nuclear issue in the media; however, to the best of our knowledge, no cross- cultural studies have been conducted to compare and contrast the dialogic positioning taken by the Iranian and Western media regarding the Iranian nuclear issue. The current study aims to investigate the dialogic positioning taken by the media during the nuclear negotiations between the Iranian team and the $5+1$ countries.

\section{Theoretical Framework}

Appraisal is an approach to the analysis of evaluative language developed by a group of linguists working within the Systemic Functional Linguistics (SFL) paradigm of Halliday (1994). According to Martin and White (2005), the appraisal framework provides systematic taxonomies of what the key types of evaluative meanings are and explains how users of English convey the attitude (emotion and judgment of people) and engagement (of potential readers in the offered propositions). However, attitude is not the main focus of this study.

Under the appraisal approach, "the speaker or writer engages dialogically with prior utterances on the same topic and potential responses" (p. 61), such that he refers to what has been said or written before and at the same time anticipates the potential or imagined readers or listeners to have their own responses (White, 2012). In fact, when the authorial voice presents propositions, he does so in a way to acknowledge that the value position which is advanced is just "one of a number of potential dialogistic alternatives" (White, 2012, p. 61). In this regard, Fairclough (1985) states that when the speaker or writer adopts a particular position and therefore engages with others, he can be said to be negotiating with an ideal hearer or speaker. Martin and White (2005) propose various subcategories within the domain of engagement making a distinction between dialogic contraction and dialogic expansion which will serve as the basis for the interpretation of the media extracts in this study.

\subsection{Dialogic Contraction}

According to Martin and White (2005), contractive meanings are used by the journalists to challenge the scope of alternative value positions. This is despite the fact that, the journalist claims to be sharing the readers' 
Dialogic positioning in Iranian versus Western media coverage of the Iranian nuclear issue

viewpoints. Contractive meanings can be divided into two categories: Disclaim and Proclaim (Table 1).

\section{Table 1}

Contractive dialogic Positioning (adopted from White, 2012, p. 65)

\begin{tabular}{ll}
\multirow{2}{*}{ Contract } & a) disclaim: deny (no, didn't, never), counter (yet, although, but) \\
& b) proclaim: concur (of course, obviously), pronounce (indeed, because), endorse (show, prove).
\end{tabular}

The category Disclaim including denials (no, didn't, never) and counter-expectationals (yet, although, but) refers to meanings by which some alternative position is introduced in the text. That is, the journalist is presented as either rejecting the opposing propositions, as in the case of denials or countervailing some anticipated expectations, as in the case of counter-expectationals.

The category Proclaim, on the other hand, refers to the expressions through which the journalist acts to limit the scope of dialogistic alternatives, which are presented as valid, without directly rejecting them. These expressions are identified into three subcategories: (i) concur, which includes expressions which explicitly present the journalist as agreeing with or sharing the same views as the text's putative addressee (The act of parliament will, of course, benefit our country). Other words in this regard are adverbials such as naturally, obviously, admittedly (ii) Pronounce, or expressions through which the authorial voice puts an emphasis on the value of his or her proposition (I contend that...). Also, through the reinforcing formulations, the quoted source can be presented to have made a pronouncement in opposition to some alternative position (the facts of the matter are...), thus reducing space in any upcoming interaction and, (iii) Endorse, or expressions through which the author enters into a form of negotiation with the addressee and presents the attributed information as reliable and takes responsibility for it (the report demonstrates/shows/proves that...).

\subsection{Dialogic Expansion}

Martin and White (2005) point out that some expressions allow the journalist to open up the dialogic space in the text for alternative positions and textual voices. Under the title of dialogic expansion, two main categories can be distinguished: Entertain and Attribution (Table 2).

\section{Table 2}

Expansive Dialogic Positioning (adopted from White, 2012, p. 65)

\begin{tabular}{|c|c|}
\hline & entertain (perhaps, must, apparently, expository questions) \\
\hline Expand & $\begin{array}{ll}\text { attribute } & \text { a) acknowledge (argue, state) } \\
& \text { b) distance (claim) }\end{array}$ \\
\hline
\end{tabular}

The category Entertain refers to wordings by which the authorial voice indicates that his or her position is one among different possible positions, leaving space for them dialogically. Indicating individual subjectivity of the authorial voice, this category includes : (i) meanings of likelihood, conveyed by expressions such as modal auxiliaries (may, could, must, etc.), modal adjuncts (perhaps he is hiding in his underground cellar), modal attributes ( it's possible that...) and some mental verbs (I suppose, I believe, I'm convinced that...; (ii) meanings of evidence and appearance, through which the journalist reveals his subjective deduction opening up dialogic space for other alternatives(It appears that...); (iii) directives and deontic modality locutions, such as those indicating permission and obligation (You must pay attention to the traffic signs while driving), and, finally (iv) expository or open ended rhetorical questions (What questions would you want to ask the author if you ever met him/her?). According to Hyland (2002), through the employment of questions, the speaker or writer can best engage the readers dialogically which will finally end up in agreement with his/her viewpoints.

The category Attribution, deals with the journalist's strategy which, by quoting others directly and indirectly, he or she includes other points of views. This category includes verbs which refer to the communicative and mental processes (e.g. He says /thinks that...) and various adverbial adjuncts (e.g. according to, in X's view). 
Martin and White (2005) distinguish two subcategories of Attribution: (i) Acknowledge, through which the authorial voice, without referring to his own position, takes a neutral stance. In other words, through attribution of the propositions to the quoted sources either directly or indirectly, he attempts to pass on the observations, interpretations, beliefs, and opinions to the media audience (e.g. Arguing that...he describes...; the government says that...). Here, reporting verbs carry a remarkable role as they are indicative of the reporter's impersonalized voice. (ii) Distance, in which the speaker/writer explicitly disassociates him/herself from the attributed information, thus declining to take responsibility for its truthfulness (e.g. The spokesman has claimed that...). In fact, using this kind of reporting verbs, the journalist him/herself has no belief in what is being reported, through which his/her underlying ideology regarding the reported matter could be traced.

\section{Literature Review}

Media language has long been a popular research focus for linguists who work with language and communication or media studies. It has been so, since media today are easily accessible to people, and are naturally very likely to influence them, such that the way people use language for social meanings and express their attitudes and beliefs about different issues can be traced back to media (Bell \& Garrett, 1998).

Media discourse has been analyzed from different aspects, for instance from sociolinguistic perspectives (Bell, 1991), critical linguistics (Fowler, 1991) and social theory (Fairclough, 1995a). Considering social and cultural aspects of language, Bell (1991) mentions that language constitutes social reality and also reflects it. Emphasizing the use of functional linguistics in analyzing news discourse, Fowler (1991) calls for the contextualized, practical use of language which can provide specific assessments for critical audience since it establishes a relationship between them and authors. Fairclough (1995b) also emphasizes the essential relationship between language, society and power. In fact, the linguistic features in media discourse have been associated with social values, in order to investigate how ideologies are conveyed in news coverage and how power relations are produced through discourse. Also, van Dijk (1995) mentions that media have the potential to control to some extent "the actions and minds of the dominated group members in the interest of the dominant group" (p. 20), that is, their intentions, plans, knowledge, beliefs, or opinions. However, since ordinary people usually accept news reports as true or journalistic opinions as legitimate or correct, mind control by the media can be effective providing the media users do not realize this control (van Dijk, 1995) due to the choice of resources as well as textual voices employed in media discourse.

Media discourse involves different issues. Among these issues, political discourse has always played a major role in leading the society towards the goals of the elite or the governments. The speeches of politicians, parliamentary debates, textbooks, and political essays (Tekin, 2008) have been an interesting area for a sizable body of research in recent years as political events have established themselves as the basis for various development in a country (Lauerbach \& Fetzer, 2007). Drawing on van Dijk's (1999) socio- cognitive approach and Fairclough's (1995a) approach of intertextual analysis of news discourse and within the paradigm of Critical Discourse Analysis (CDA), political discourse in media interprets and represents ideas ideologically.

Employing rhetorical techniques, media color speakers of in-group politicians and downplay those of outgroup statesmen in different quantities (Bhatia, 2006). In other words, media consciously use different resources to satisfy their purposes (Bloor \& Bloor, 2007). White (2012) provides a good example: "using a regime of strategic impersonalisation, media are often able to advance or favor a particular value position while employing a relatively impersonal style in which attitudinal evaluations and other potentially contentious meanings are largely confined to material attributed to quoted sources"(p. 57).

He also shows that, for example, the use of hedges can be an instrument of reducing the effect that a sentence can have, that is, the expansively dialogic positioning that the writer adopts in order to engage the readers. On the other hand, the implementation of adverbial intensifiers reflects the contractively dialogic positioning that the writer adopts in order to limit the scope of alternatives and has the intended influence on the 
readers' minds. Such strategies are used by media to steer public attention towards the direction they favor; this way, they try to provide the public support the elite require to fulfill their intentions or in Allen's (2007) words, through employing such rhetorical techniques media can highlight positive aspects of the in-group politicians and negative aspects of their opponents. In so doing, there are some complexities journalists go through in news production process which according to White (2012) may cause different representations of reality. It is to be noted that the comparison and contrast of political discourse in opposing media and the processes that shape it can reveal the manipulative ways through which information, values, ideologies, and beliefs are conveyed to the readers in the course of political issues.

\section{Methodology}

To accomplish the aims of the study, we downloaded some texts from five Iranian and five Western media regarding the Iranian nuclear issue for analysis. They were from March 19 to December 18, 2014. The news and opinion coverage of the five Iranian media examined in this study included: Press TV, Tehran Times, Fars News Agency, IRNA, and IRDIPLOMACY. These media were selected because they are the most famous and influential in Iran and outside Iran, especially that they are all state- run and represent the Iranian government. They may have some different viewpoints and perspectives regarding the Iranian nuclear program; however, since the nuclear program in Iran is regarded a national issue, they produce the same voice.

The news and opinion coverage of the five Western media examined in this study included: The New York Times, Washington Post, The Jerusalem Post, The Guardian, and Reuters. These media were selected because they include some of the largest news agencies in the United States, as well as those widely covering foreign policy issues in Britain, and Israel. Each paper also represents a distinct political and ideological perspective; those that favor international intervention in Iran and those that are of the idea to adhere to the international institutions to address the dispute. However, the point in which they are all united is that Iran should be stopped from making nuclear progress.

The texts employed for the analysis are concerned with the issues related to Iran's nuclear program which have been of discord between this country and the Western countries since at least 2000. Some examples in this respect are demanding sanctions relief, expressing Iran's right to nuclear energy, extension of the talks, and uranium enrichment.

The texts were of news reports and editorial types. Our criterion for selecting the extracts was that they needed to be covering the same issues from both sides, so that they could be comparable and the results generalizable. While, the writers of the selected texts were mainly journalists or correspondents, i.e. they were not representatives of governments, MPs, government spokesmen or officials of any government administrations.

The extracts selected were minimum of two clauses and maximum of six clauses to cover the nuclear issues. Off course, it is common that political texts normally cover several issues at the same time. However, analyzing them all at the same time must create complexities as far as discourse analysis is concerned. As the role of context is significant, the extracts had to be carefully selected in order to put the readers in the same contextual conditions so that a good understanding would come about. The extracts selected were analyzed based on Martin and White's (2005) appraisal framework distinguishing the journalists' dialogic positioning to see how the Iranian and Western media differ in conveying their ideologies and ways of thinking to their audience.

\subsection{Employment of Expansive Dialogic Position in the Iranian Media}

\section{Extract 1}

Iran may never be able to satisfy Western demands for assurance over its nuclear program. (Tehran Times, 19 May, 2014) 
In the above extract, the reporter uses the epistemic modal verb may to stop short of categoricality in the assertion, in order to make the proposition controversial and to engage the readers ' ideas about it. In fact, the utterance has been made in such a way that readers will not completely reject the reporter's idea, rather it will just be a matter of opinion as to the details of coping with the West in the negotiations.For example, some in Iran may believe by satisfying Western demands, Iranian needs will also be met. In this way, the authorial voice, providing the proposition, acknowledges that the value position being advanced is just among the potential dialogistic alternatives. Therefore, it is a case of expansive dialogism.

\section{Extract 2}

The two sides seem to be very interested in coming to an agreement. (Tehran Times, 20 March, 2014)

Here, the evidential seem to be leads the journalist to have an expansively dialogic position, allowing for other alternatives, that is, whether the two sides are really very interested or it is just a show either side is putting on. In other words, the proposition is subjectively based as a result of the journalist's deduction process and presented as one among a range of potential alternatives.

\section{Extract 3}

France appeared to be concerned that the proposal, ..., did not apply the brakes hard enough on the countries agenda. (IRDIPLOMACY, 11 November, 2014)

In the above extract, as in the previous one, showing lack of certainty, the journalist has employed the verb appeared to acknowledge potential dialogistic alternatives about France's concern about Tehran's commitment to curtail its nuclear program. For example, some may believe that France's concern in this regard could have been a political strategy and the like. So the journalist's position is expansive.

\section{Extract 4}

Iranian Deputy Foreign Minister Majid Takht-Ravanchi said that a deal can be struck if the other side engages in the negotiations in "good faith" and if Iran's "nuclear rights" are upheld. (Tehran Times, 2 July, 2014)

Attribution is involved via the neutral verb said in the above extract. The epistemic modal verb can here also shows a dialogic positioning on the part of the quoted source. Apart from this, the conditions presented by the quoted source, using if, add to the lack of definitiveness of the proposition, widening the space in the text for various alternatives. All of the characteristics mentioned above indicate expansively dialogic positioning on the part of the journalist as well as the quoted source.

\section{Extract 5}

Iran may accept some short-term constraints on its nuclear program..., a senior Iranian negotiator said in an interview with ISNA which was published on Wednesday. (Tehran Times, 2 July, 2014)

In this extract, the epistemic modal verb may is employed to keep off a definitive answer. There is also the verb said, which is a case of attribution of the presented proposition to a specified source. Here, both the modal verb and the reporting verb are an indication of the expansive perspective, since they share the property of explicit subjectivity, signaling that it is one among a range of possible dialogic options.

\section{Extract 6}

US Secretary of State John Kerry and French Foreign Minister Laurent Fabius are reportedly due to join the talks. (Tehran Times, 12 July, 2014)

Here, the journalist shows his expansively dialogic positioning through the adverb reportedly with which he 
Dialogic positioning in Iranian versus Western media coverage of the Iranian nuclear issue

keeps an impersonalized style, attributing the proposition to, of course, an unspecified source.

\section{Extract 7}

Iran and the major powers will extend their talks..., according to a source close to Iran's nuclear negotiating team. Tehran Times, 17 July, 2014)

In this extract, using according to the author stands neutral as to the offered report and keeps an impersonalized style which is a case of expansive dialogism.

\subsection{Employment of Contractive Dialogic Position in the Iranian Media}

\section{Extract 8}

Iran has never been after an atomic bomb or a military nuclear program. (Press TV, 14 July, 2014)

The journalist, in the above extract, has reacted to the accusations made against Iran regarding its nuclear program. In this respect, his choice of the disclaiming term never to express his stance puts him on the contractive dialogism. In fact, the journalist, using the denial, has tried to limit the scope of the alternatives and establish his idea in the minds of the readers.

\section{Extract 9}

Remember that Iran has been under the most man-hours of International Atomic Energy Agency (IAEA) inspections and all its programs have endorsed so far, and the IAEA has repeatedly stressed that it has $\underline{\text { not }} \underline{\text { seen }}$ any kind of diversion in Iran's civilian nuclear program. (Press TV, 14 July, 2014)

Here, the journalist has employed the type of verbs indicating contractive dialogism remember, endorse, stress, and see asserting his own idea and contracting others. Also, based on the formulations employed, that is, the intensifiers the most, all, and so far and the concurring term repeatedly as well as the negation not, it can be judged that the journalist has taken a contractively dialogistic position and is trying to assert his belief into the minds of the readers although he has the claim of sharing their viewpoints. This is conducted by the argumentation the journalist supplies considering the readers as needing some information on the subject.

\section{Extract 10}

Iran has already agreed to significant guarantees that its nuclear program is for civilian purposes - and $\underline{\text { not }}$ for weaponization, as the US, Britain and France have long been claiming - by agreeing to cap uranium enrichment at levels far below that required to make atomic bombs. (Press TV, 11 June 2014)

Here, the journalist has used some attitudinal terminologies in order to encourage the readers to be in the expected frame of mind. The phrases significant guarantees, civilian purposes, and far below present Iran to be abiding by the IAEA rules and even going beyond that in order to remove any grain of doubt as to its nuclear activities. In this regard, the verbs agree, cap, and require, together with the intensification already, and the negation not reveal the journalist's contractively dialogic position. Although, the word weaponisation bears a negative attitude, it has been attributed to the Western side employing the reporting verb claim which disassociates the journalist with the quoted source.

\section{Extract 11}

The five per cent enrichment limit agreed to by Iran six months ago is a goodwill gesture that Iran has freely conceded to in order to prove its constant claim that its nuclear program is for peaceful civilian uses, such as energy production, medical isotopes and scientific research. (IRNA, 19 May, 2014)

The use of the attitudinal terms such as limit, goodwill, constant, peaceful, and scientific shows that the 
Ghane, M. H., Allami, H., \& Mahdavirad, F.

journalist is trying to frame a conformist picture of Iran in the readers' minds. As far as dialogic positioning goes, the verbs agree, concede, and prove and the adverb freely all connote the journalist's contractive disposition. In fact, he is trying to produce a totally positive view of Iran and its nuclear activities for the readers, confining the scope for alternatives in the minds of the potential readers in this regard.

\section{Extract 12}

In a recent article published in the Washington Post, U.S. Secretary of State John Kerry clearly declared that Iran has completely fulfilled its commitments over the past few months. (Tehran Times, 2 July, 2014)

Employing a quotation from the Western side which includes the phrase completely fulfill its commitments, the author seems to advance a positive positioning regarding Iran although he claims neutrality through the verb declare. The verb fulfill connotes a positive picture and the proclaiming adverbs completely and clearly, adding to the dialogic contraction of the author, involve a positive orientation.

\section{Extract 13}

"...of course we have some difficulties, some hurdles so that is why we have to work together and in the spirit of cooperation and mutual respect," Chinese Deputy Foreign Minister Li Baodong added. (Press TV, 14 July, 2014)

Here, the choice of the quotation from the Chinese official as a member in the negotiating team seems to be indicative of a positively axiological position or optimism regarding the negotiations, since it includes a positive stance on the part of the quoted source. The word hurdle implies a difficulty which is surmountable, and the phrase in the spirit of cooperation and mutual respect shows a positive stance. The quotation has taken a contractively dialogic position through the use of the proclaiming term of course and the contractive verb added. The term of course construes the audience to share his view about the difficulties in the way of reaching an agreement. Regarding the verb add, although an act of attribution is made on the part of the journalist through the reported speech, which is an indication of the subjectivity of the authorial voice, he shares responsibility for it with the cited source.

\subsection{Employment of Contractive Dialogism in the Western Media}

\section{Extract 14}

Iran's Foreign Ministry questioned the practicality of a self-imposed July 20 deadline for the parties to reach a comprehensive nuclear agreement this week. (Jerusalem Post, 3 July, 2014)

Again, although an act of attribution is involved, since the reporting verb question shows no neutrality and the journalist seems to take responsibility for its validity, it is a case of endorsement showing the journalist's contractively dialogic perspective. It is also negatively attitudinally disposed since the journalist shows a blaming tone towards the Iranian official accusing Iran to be reluctant to quickly reach an agreement.

\section{Extract 15}

Recent initiatives have focused more on short-term confidence-building measures rather than a negotiated agreement resolving the nuclear issue. (New York Times, 8 April, 2014)

The reporting verb in the above extract have focused is a reinforcement verb. In other words, the journalist, emphasizing that the short term measures are preferable in the time being, has tried to suppress any other alternative opinions on the part of the addressees. Also, the adversative rather than presents the journalist as countervailing the assumed expectation, that is, a negotiated agreement. Hence, he is presumed to have adopted a contractively dialogic positioning. 


\section{Extract 16}

The talks... are aimed at reaching a permanent agreement $\underline{\text { intended }}$ to ensure that Iran cannot $\underline{\text { develop }}$ a nuclear weapon. (Washington Post, 19 March, 2014)

The above extract indicates a contractively dialogic positioning on the part of the journalist. This is revealed through these lexical choices: the verbs aimed at, reaching, intended, ensure, develop, and the negation not. Through these lexical devices the journalist has tried to steer the readers' minds to the direction that Iran' nuclear activities have been proved to be unpeaceful and the talks are held to stop it from developing them.

\section{Extract 17}

In a Washington Post tribune, he warned Iran not to "squander a historic opportunity to end Iran's economic and diplomatic isolation and improve the lives of their people. (The Guardian, 3 July, 2014)

The reporting verb warn and the negation not which indicate contractively dialogic positioning, together with the quotation indicating disastrous living conditions in Iran, are pretentious of the author's goodwill and put the blame on the Iranian government for the failures in the negotiations. Therefore, the author standing with the proposition presented, seems to be trying to urge the readers to have the same viewpoint.

\subsection{Employment of Expansive Dialogism in the Western Media}

\section{Extract 18}

US Under Secretary of State for Political Affairs Wendy Sherman said it was Iran that would need to shift its position. (Jerusalem Post, 22 June, 2014)

In the above extract, there is the neutral reportative verb said through which the reporter tries to attribute the proposition to the source of the information together with its description so that the reader can assess the reliability of the information. Here, through attribution, the reporter tries to put the responsibility of the proposition on the shoulders of the quoted source, although he/she is him/herself responsible for this act of attribution. Another matter which puts the reporter on the expansively dialogistic positioning is the modal verb would. This indicates that the journalist, having no concrete information, is trying to occupy the potential readers' minds with the idea that Iran's nuclear program is unpeaceful and Iran has to make reconsiderations in this regard.

\section{Extract 19}

Iran says its nuclear program is entirely peaceful. (Reuters, 8 April, 2014)

The authorial voice has used the unmarked reporting verb say to stay neutral to the proposition. In fact, avoiding categorality, he/she has tried to engage the readers' minds in this regard.

\section{Extract 20}

Iran nuclear deal loophole may allow off-site reactor work. (Jerusalem Post, 14 June, 2014)

Here, the use of the modal verb may indicates the journalist's lack of certainty and limited degree of knowledge about Iran's nuclear activities. Therefore, he/she avoids formulating a categorical proposition and takes an expansively dialogic stance.

\section{Extract 21}

A senior American official described the sessions as "intense" and said there were discussions of Iran's uranium enrichment program, the construction of a heavy water reactor at Arak that could be used to make plutonium into a fissile material. (New York Times, 19 March, 2014) 
In this extract, the verb describe does not overtly indicate where the authorial voice stands with respect to the proposition. However, he/she has claimed impersonalization through the reporting verb said in order to pass the buck. In addition, he/she has used the epistemic modal verb could showing his lack of certainty. Therefore, the neutral verb said, the expansive verb describe, and the epistemic modal verb could are the indication of the journalist's expansive dialogic positioning.

\section{Extract 22}

According to US diplomats, those gaps are numerous and are wider than many had expected. (Jerusalem Post, 14 July, 2014)

In this extract, the author presents the attributed proposition for the readers' consideration using the reportative according to, a case of expansively dialogic positioning.

\section{Extract 23}

World powers suspect Iran seeks atomic weapons, which Iran denies. (The Guardian, 19 July, 2014)

The above extract can be interpreted in two ways: in terms of lexicon and dialogistic positioning. In terms of lexicon, the word suspect and the phrase atomic weapons show a negatively opinion based orientation towards Iran, implying that Iran is trying to endanger world peace. In terms of dialogistic positioning, the reporting verb suspect shows the journalist's avoidance of categorality and, therefore, expansively dialogic positioning; however, quoting world powers is an effort on the part of the journalist to produce an evaluation of high certainty or reliability. In this way, he/she has tried to organize his/her utterance in such a way that the alternative positions, which are being allowed for, would not reject his/her viewpoint.

\section{Extract 24}

Zarif said other conditions could be inserted into a deal that would give extra assurances to the international community that Iran could not make a nuclear weapon quickly. (Washington Post, 15 July, 2014)

Here, the author has used the attributive reporting verb said to pretend an impersonalized style of reporting the fact; however, he/she has employed attitudinal terminology which shows the opposite, especially that the terminology is claimed to have been uttered by an Iranian high ranking official. The phrase nuclear weapon shows the author's lack of neutrality. Not quickly in the last phrase implies that the quoted source meant that Iran is planning to produce a nuclear weapon although not quickly. Also, using the epistemic modal verbs could and would, the author has tried to avoid categoricality and to engage the readers. However, with the line of vision presented by the author, he/she has tried to make the readers not reject his/her ideas. Therefore, the use of the neutral verb and the epistemic modal verbs make the author fall on the expansive side. Besides, using the phrase international community, the writer has tried to make the readers think of Iran as an isolated country, hence, negatively attitudinally disposed.

\section{Results of Quantitative Analysis}

To analyze the data regarding the journalists' positioning in order to manipulate the readers' minds, we employed a Chi-square test. Figure 1 displays the difference between the Iranian and the Western media in terms of the strategy of dialogistic positioning which is divided into contractive and expansive positions.

As can be seen in the figure, although the number of both contractive and expansive verbs and expressions employed by the Western journalists is larger than the one employed by the Iranian journalists, they both seem to have the same tendency. In other words, both Iranian and western journalists have made use of the contractive dialogic positioning more than expansive dialogic positioning. 


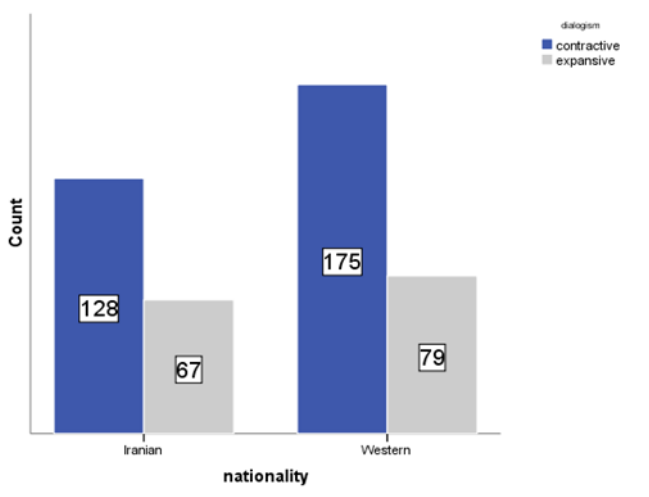

Figure 1. Contractive and expansive dialogic positioning in Iranian and Western media

Table 3

Descriptive Statistics of Dialogic Positioning

\begin{tabular}{|c|c|c|c|c|c|}
\hline & & & \multicolumn{2}{|c|}{ dialogism } & \multirow{2}{*}{ Total } \\
\hline & & & contractive & expansive & \\
\hline \multirow[t]{8}{*}{ Nationality } & Iranian & Count & 128 & 67 & 195 \\
\hline & & $\%$ within nationality & $65.6 \%$ & $34.4 \%$ & $100.0 \%$ \\
\hline & & $\%$ within dialogism & $42.2 \%$ & $45.9 \%$ & $43.4 \%$ \\
\hline & & $\%$ of Total & $28.5 \%$ & $14.9 \%$ & $43.4 \%$ \\
\hline & Western & Count & 175 & 79 & 254 \\
\hline & & $\%$ within nationality & $68.9 \%$ & $31.1 \%$ & $100.0 \%$ \\
\hline & & $\%$ within dialogism & $57.8 \%$ & $54.1 \%$ & $56.6 \%$ \\
\hline & & $\%$ of Total & $39.0 \%$ & $17.6 \%$ & $56.6 \%$ \\
\hline \multirow{4}{*}{\multicolumn{2}{|c|}{ Total }} & Count & 303 & 146 & 449 \\
\hline & & $\%$ within nationality & $67.5 \%$ & $32.5 \%$ & $100.0 \%$ \\
\hline & & $\%$ within dialogism & $100.0 \%$ & $100.0 \%$ & $100.0 \%$ \\
\hline & & $\%$ of Total & $67.5 \%$ & $32.5 \%$ & $100.0 \%$ \\
\hline
\end{tabular}

As can be seen in the table above, the Iranian and Western journalists' use of contraction is $65 \%$ and $68 \%$ respectively, which are very close to each other. Also, their use of expansion is $34 \%$ and $31 \%$ which are again very close to each other and therefore, there is no significant difference between them. The effect size of the difference mentioned above is displayed in Table 4.

\section{Table 4}

The Effect Size of Journalists' Strategy of Dialogism

\begin{tabular}{clcc}
\hline & & Value & Approx. Sig. \\
\hline \multirow{2}{*}{ Nominal by Nominal } & Phi & -.034 & .465 \\
& Cramer's V & .034 & .465 \\
N of Valid Cases & 449 & \\
\hline
\end{tabular}

It can be seen that the phi coefficient is .03 which is lower than the small effect size (.10), as proposed by Cohen (1988).

Obviously, the journalists attempted to pretend to be sharing their readers' views, however, their contractively dialogic positioning in the act of engaging their readers revealed their attempt to challenge or suppress the potential different alternatives, in order to influence people's ideas. This strategy of journalists was, 
indeed, in support of their respective supportive powers to provide them with public support in order to reach their national and international goals. This matter seems mostly due to the fact that the context of the institutions in which the journalists work has influenced the journalists both consciously and subconsciously. As it is, journalists and reporters are seldom direct witnesses to events and their data are mostly other discourses. Thus, due to being exposed to the views rampant in the context of the workplace the journalist, perhaps unknowingly, gets the impression that the views are based on strongly grounded basis.

\section{Discussion and conclusion}

This study tried to explore the dialogic positioning of the journalists in Iranian versus Western media coverage of the Iranian nuclear issue. To do so, mostly the lexical choices, hence stance markers were used by the Iranian and Western media regarding Iranian nuclear program, which shows their political line of vision.

The results of this study show that the Iranian and Western media hold opposite positions regarding the Iranian nuclear issue and employ different linguistic devices when reporting the $5+1$ negotiations as well as other developments in this regard. Although both the Iranian and Western media might have controversy in different issues amongst themselves, each seems to have taken a united warfront against the other regarding the Iranian nuclear program. On the one hand, there is a national and patriotic feeling amongst the unanimity of Iranians to be on a par with the world in terms of science and technology which creates a sensationally national context. Naturally, the Iranian journalists have tried to reflect this sensation; although there is a fluctuation of the degree of agreement among the Iranian journalists, on the whole, their tone and style of writing is supportive and persuasive of the nuclear program in Iran.

The Western media, on the other hand, have all taken a hesitative or even harsh tone against a nuclear Iran. This is sometimes even to the point that when reaching an agreement in the negotiations between Iran and the $5+1$ countries was probable , they would put forward other issues such as accusing Iran of human rights violation and helping the Jihadi organizations in the middle east. Many of these media, as well as the Iranian media, rely monetarily upon their governments, and naturally the positions they take constitute the ideological representation and the political stance of their governments. It is supportive of Fishman (1980) stating that "news is not simply an incomplete description of the facts, but a specific (re)construction of reality according to the norms and values of some society" (as cited in van Dijk, 1983, p. 28). Therefore, since the values in the Iranian and Western society greatly differ, their representations emerging in the media of both sides can be divulged if considered critically.

The political positions held by the media account for the linguistic devices, such as reporting verbs, quotations, modality and other lexical choices, constituting the dialogic positioning chosen and used in news reporting. In terms of political stances, the Iranian media selected quotations from Iranian officials who stipulated Iran's right to have peaceful nuclear energy based on the NPT and also quotations from the Western official or media which acknowledged Iran's right or the cooperation Iran had made in order to remove the misunderstandings. Naturally, they employed terminology with positive attitude and quotations which justified Iran's nuclear activities in spite of the accusations made towards Iran. Conversely, the Western media employed quotations including negatively attitudinal terminology which accused Iran of violating the international rules or even trying to produce nuclear weapons secretly in order to endanger the international tranquility. However, neither side tried to confirm the other side's prerogative to express its worry regarding the mentioned issues.

This is all in line with what Perrin (2012) mentioned that "stance determines the selection of certain topics, topical aspects, and quotes" (p. 136). Correspondingly, it implies the omission of others, which unlike the selected ones, do not appear in the text product (Perrin, 2012). In addition, the employment of the attitudinal terminology in the analyzed extracts supports the view of Martin and White (2005) that writers try to bring about specific assessments. It becomes clear that in order to favor or disfavor an issue, journalists make use of attitudinal terminology which reveals the journalist's ideology. 
Dialogic positioning in Iranian versus Western media coverage of the Iranian nuclear issue

It is of course that research is not value free since researchers inevitably influence their findings (Watson, 1994). This can again be related to van Dijk's (1995) idea that cognitive influence leads to the subjective interpretations. Therefore, the researchers are open to criticism with regard to his interpretations of the media extracts conducted. In sum, the findings of this research and other similar studies which focused on the discourse of newspapers (e.g. Behnam \& Mahmoudi, 2013; Hodge \& Kress, 1979; van Dijk, 1999) show that the events are not represented in the newspapers as they are in reality, but go through journalistic practices.

\section{References}

Allen, W. (2007). Australian political discourse: Pronominal choice in campaign speeches. In M. Laughren \& I. Mushin (Eds.), Selected papers from the 2006 conference of the Australian linguistic society (pp. 1-13). Melbourne: Melbourne University.

Behnam, B., \& Mahmoudy, B. (2013). A critical discourse analysis of the reports issued by the International Atomic Energy Agency (IAEA) Director General. Iran's nuclear program during the last decade. Theory and Practice in Language Studies, 12(3), 2196-2201. http://dx.doi.org/10.4304/tpls.3.12.2196-2201

Bell, A. (1991). The language of news media. Blackwell, Oxford.

Bell, A., \& Garrett, P. (1998). Approaches to media discourse. Oxford: Blackwell Publishers Ltd.

Bhatia, A. (2006). Critical discourse analysis of political press conferences. Discourse \& Society, 17(2), 173-203. http://dx.doi.org/10.1177/0957926506058057

Bloor, M., \& Bloor, T. (2007). The practice of critical discourse analysis. London: Hodder Education.

Cohen, J. (1988). Statistical power analysis for the behavioral sciences (2nd ed.). Hillsdale, NJ: Erlbaum.

Fairclough, N. (1985). Critical and descriptive goals in discourse analysis. Journal of Pragmatics, 9, 739-763. http://dx.doi.org/10.1016/0378-2166(85)90002-5

Fairclough, N. (1995a). Media discourse. London: Arnold.

Fairclough, N. (1995b). Critical discourse analysis: The critical study of language. London: Longman.

Fishman, M. (1980). Manufacturing the news. Austin, TX.: University of Texas Press.

Fowler, R. (1991). Language in the news: Discourse and ideology in the press. London: Routledge.

Halliday, M. (1994). An introduction to functional grammar (2nd ed.). London: Edward Arnold.

Hodge, R., \& Kress, G. (1979). Language as ideology. New York: Routledge.

Hyland, K. (2002). What do they mean? Questions in academic writing. Text, 22(4), 529-557. http://dx.doi.org/10.1515/text.2002.021

Izadi, F., \& Saghaye Biria, H. (2007). A discourse analysis of elite American newspaper editorials. The case of Iran's nuclear program. Journal of Communication Inquiry, 31(2), 140-165. http://dx.doi.org/10.1177/0196859906298073

Lauerbach, G. E., \& Fetzer, A. (2007). Political discourse in the media: Crosscultural perspectives. In A. Fetzer, \& G. E. Lauerbach (Eds.), Political discourse in the media (pp. 3-28). Amsterdam: John Benjamins. http://dx.doi.org/10.1075/pbns.160.031au

Martin, J., \& White, P. R. R. (2005). The language of evaluation: Appraisal in English. Houndmills Basingstoke, Palgrave Macmillan. http://dx.doi.org/10.1057/9780230511910

Perrin, D. (2012). Strategies of entextualizing stance in newswriting. Discourse, Context \& Media, 1(2-3), 135-147. http://dx.doi.org/10.1016/j.dcm.2012.10.005

Shojaei, A., Youssefi, K., \& Shams Hosseini, H. (2013). A CDA approach to the biased interpretation and representation of ideologically conflicting ideas in western printed media. Journal of Language Teaching and Research, 4(4), 858-868. http://dx.doi.org/10.4304/jltr.4.4.858-868

Siegel, J., \& Barfroush, S. (2013). Media coverage of Iran's nuclear program. An analysis of U.S. and U.K. coverage, 2009-2012. Center for International and Security Studies at Maryland, School of public policy, University of Maryland.

Tekin, B. C. (2008). The construction of Turkey's possible EU membership in French political discourse. Discourse \& Society, 19(6), 727-763. http://dx.doi.org/10.1177/0957926508095891

van Dijk, T. A. (1983). Discourse analysis: Its development and application to the structure of news. Journal of 
Ghane, M. H., Allami, H., \& Mahdavirad, F.

Communication, 33(2), 20-43. http://dx.doi.org/10.1111/j.1460-2466.1983.tb02386.x

van Dijk, T. A. (1995). Aims of critical discourse analysis: Japanese Discourse, 1, 17- 27.

van Dijk, T. A. (1999). Towards a theory of context and experience models in discourse processing. In H. van

Oostendorp \& S. Goldman (Eds.), The construction of mental models during reading (pp. 123-148).

Hillsdale, NJ: Erlbaum.

Watson, T. J. (1994). In search of management. London: Routledge.

White, P. (2012). Exploring the axiological workings of reporter voice news stories attribution and attitudinal positioning. Discourse, Context \& Media, 1(2-3), 57- 67. http://dx.doi.org/10.1016/j.dcm.2012.10.004 